\title{
EVALUATION AND PREDECTION OF STRUCTURAL PROPERTIES OF ASPHALT CONCRETE
}

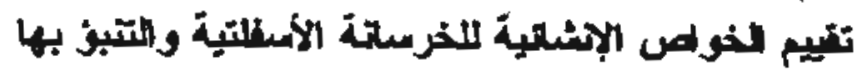 \\ Mokamed Ebaid Abrdet-Motaleb \\ Lecturer, Faculty of Engineering, Zagazig University, Egypt
}

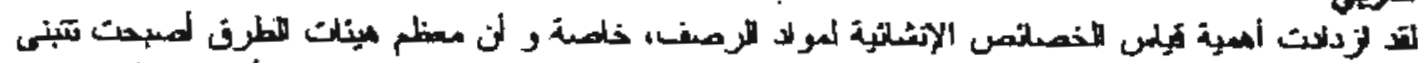

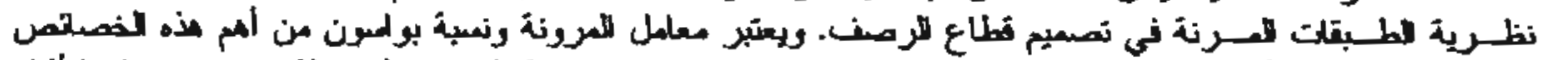

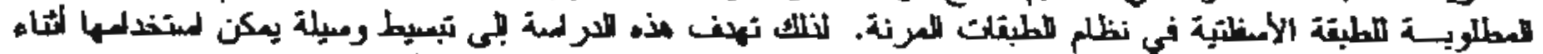

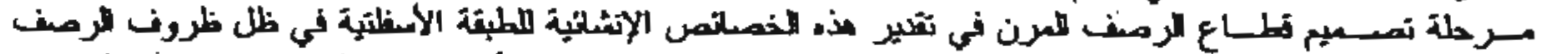

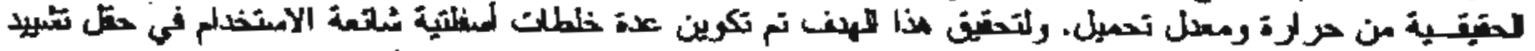

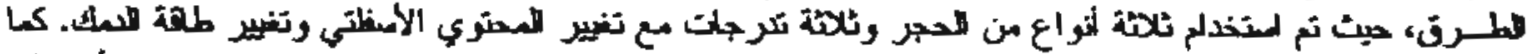

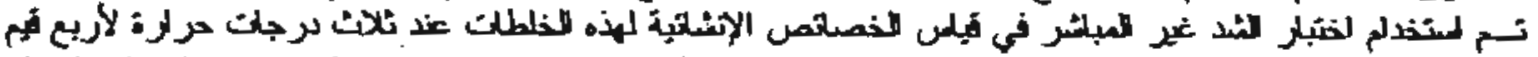

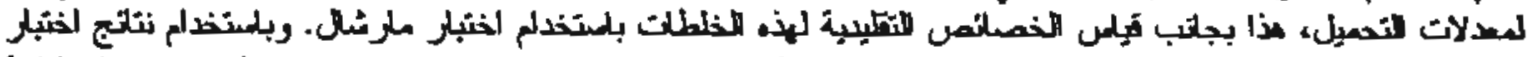

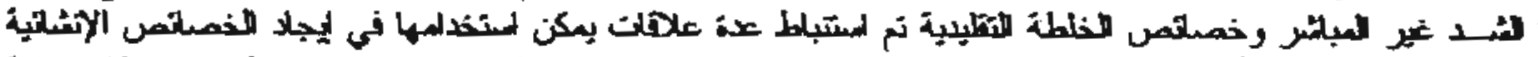

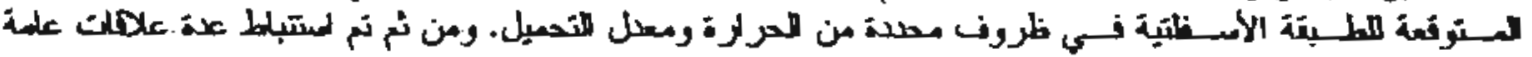

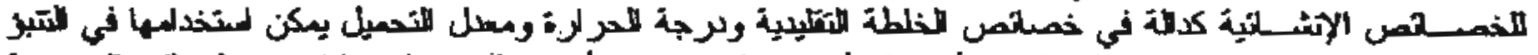

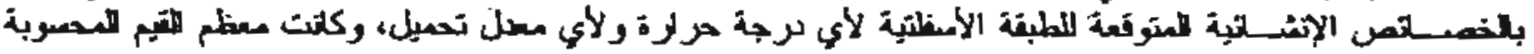

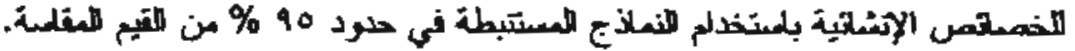

\section{ABSTRACT}

The ability to characterize paving materials in terms of fundamental properties is becoming increasingly more important. This is partially due to the fact that many agencies are beginning to use pavement design system based on elastic theory. The most required inputs in the elastic theory are Elasticity modulus (E) and Poisson's ratio $(\mu)$ of asphalt layer. So, the current study is primarily concerned with simplifying a technique that can be used in pavement design phase, for predicting the expected structural properties of asphalt layer at the actual temperature and loading rate of traffic. To achieve this objective, many paving mixes typically used in pavement constuction, were formed using different aggregate types and gradations, asphalt contents and compaction efforts. Then, the structural properties of these mixes were measured using indirect tensile test at three test temperatures along with four rates of loading. Also routine mix characteristics of these mixes were measured using Marshall method. Prediction models for a definite combination of temperature and rate of loading were developed using the results of indirect tensile tests and routine mix characteristics. Then, a general models were developed. These models can be used to predict the expected structural properties of an asphalt mix at the actual temperature along with the expected loading ratc of trafic with the aid of routine mix characteristics. The estimated values of the investigated structural properties using the developed models are within $95 \%$ of the measured values.

\section{KEYWORDS:}

Asphatt concrete, Elasticity modulus, Poisson ratio, Tensile strength, Tensile strain, Indirect Tonsile Test, Rate of loading and Temperature. 
INTRODUCTION BACKGROUND

During the past few years, the design of flexible pavement has rapid developed from empirical and semi-empirical to pavement design systems based on elastic or viscoelastic theories $[1,2,3]$. In many applications of asphaltic concrete, the elastic characteristics of the material must be known not only to assess the behavior of the mix itself but also to evaluate the performance of an engineering structure of which the mix is a part, such as a highway pavement [4].

So, the ability to characterize asphalt concrete mixtures in terms of fundamental properties is becoming increasingly more important. This is partially due to the fact that many agencies are beginning to use pavement design systems based on elastic theory in one form or onthor for new pavement and overlay designs $[5,6]$. The basic material properties required as inputs for elastic layer analysis of an asphalt pavement are: (a) elasticity modulus of each material, including variations with temperature and rate of loading, (b) poisson's ratio for cach material, and (c) tensil strength which are primarily required for thermal or shrinkage cracking analysis [7].

Indirect tensile test has been used for measuring modulus of elasticity, poisson's ratio, tensile strain and tensile strength of paving materials $[7,8,9]$. Anderson and Hahan [10] consider tensile failure strain the most significant parameter. That is because the occurance of cracking was found to increase as tensile failure strain decreased.

So, the main objective of this study is concerned with the development of general models to simplify estimating Elasticity modulus (E), Poisson ratio $(\mu)$ and tensile strain $(\varepsilon)$ and strength $(\sigma)$ of asphalt layer at different temperatures and loading rates from routine mix characteristics along with the measured values of $E, \mu, \varepsilon$ and $\sigma$ obtained from indirect tensile test at easy testing conditions. To achieve this objective, a comprehensive experimental program was designed and explained in the following sections.

\section{EXPERIMENTAL DESIGN}

The design of experiment of this study is concerned with selecting mix variables and testing conditions most related to elastic properties of asphalt mixes to be investigated. Three types of coarse aggregate, two types of fine aggregate, three mix gradations and three compaction efforts were investigated in this study. Table (1) represents the used mix gradations and the corresponding specification limits. The different investigated mixes and their conditions are shown in Table (2). Also, three test temperatures $\left(20,40\right.$ and $\left.60^{\circ} \mathrm{C}\right)$ along with four rates of loading $(0.05,0.5,1$ and $2 \mathrm{in} / \mathrm{min}$ ) werc investigated as 12 cases of testing conditions for Temperalures ( $T$ ) and Rate of loading ( $R$ ) as shown in Table (3).

\section{MATERIALS}

Three lypes of coarse aggregates were used in this study. They are crushed limestonc, crushed dolomite and crushed basalt. Limestone was obtained from "AlHaram" quarry, Giza Governorate; dolomite was obtained from "ATAKA" quarry, Suez Governorate;and basalt was obtained from "Abu Zabal" quarry, Qalubia Governorate. The results of their qualification tests are presented in Table (4). Two types of fine aggregates were used. The first was natural siliceous sand with bulk specific gravity of 2.65 , obtained from "Fayed" quarry, Ismailia Governorate. The second type was the fine material of crushed dolomite with bulk specific gravity of 2.68 . These materials 
have been collected during coarse aggregate crushing operations. Only one type of mineral filler was used in preparing all the investigated asphaltic paving mixtures in this study. It was limestone filler of bulk specific gravity of 2.85 . Gradations of the two types of sand and mineral filler are shown in Table (5). Suez asphalt cement (60/70-penetration grade) of 1.022 specific gravity was used as bituminous material. The engineering properties of the used asphalt cement are shown in Table (6).

\section{TESTING PROGRAM}

Two major tests were conducted through the laboratory-testing program of this study. These tests are: Standard Marshall and indirect tensile tests.

\section{Marshall fest}

To determine the optimuni asphalt contents $\left(\mathrm{OAC}^{\prime 5}\right)$ and to prepare test specimens for the investigated mixes, Marshall mix design procedure was perfomed. The test criterion selected was for a 75 blows Marshall compaction according to ASTM D1559.71 and AASHTO T-245.

\section{Indirect Tensile Test}

Indirect tensile test is cartied out by loading test specimens (Marshall specimen) with compressive vertical loads that act parallel to and along the vertical diameter plane until failure using the specified rate of loading. The test set up is the same used in privious work $[11,12,13]$, in which steel loading strip 0.50 in wide with a curved loading surface is used to distribute the load uniformly and to maintain a constant loading area. Also, three arms attached with micrometers dial gauges (sensitivity 0.01 $\mathrm{mm}$ division) are clamped on the samples. One vertically for measuring vertical deformation (Y). Whereas a device consisting of two cantilevered armes are clamped horizontally on the opposite sides of the sample for measuring the horizontal deformation (X). The structural characteristics measured form this test were calculated using the simplified equations developed by Kennedy [7] for 4.0-inch diameter specimen as follows:

I - Indirect tensile strength; $\sigma$

$$
\sigma=0.156 \mathrm{P} / \mathrm{H}
$$

2- Poisson's ratio; $\mu$

$$
\begin{array}{r}
\mu=(0.0673 \mathrm{DR}-0.8954) / \\
(-0.2494 \mathrm{DR}-0.0156)
\end{array}
$$

3-Modulus of Elasticity; $\mathrm{E}$

$$
\mathrm{E}=\mathrm{P} /(\mathrm{X} \mathrm{H})(0.2692+0.9974 \mu)
$$

4- Tensile stain; $\varepsilon$

$$
\begin{gathered}
\varepsilon=X(0.03896+0.1185 \mu) / \\
(0.0673+0.2494 \mu)
\end{gathered}
$$

Where:

$$
\begin{aligned}
& \mathrm{P}=\text { Total load at failure (Ib) } \\
& \mathrm{H}=\text { Height of specimen (in) } \\
& \mathrm{X}=\text { Total horizontal deformation at } \\
& \quad \text { failure (in). } \\
& \mathrm{Y}=\text { Total vertical deformation at } \\
& \quad \text { Failure (in). } \\
& \mathrm{DR}=\text { Deformation ratio }(\mathrm{Y} / \mathrm{X})
\end{aligned}
$$

\section{ANALYSIS OF RESULTS}

The routine mix characteristics according to standered Marshall test of the investigated mixes are shown in Table (7). The measured values of failure loads $P$ and deformation $\mathrm{X}, \mathrm{Y}$ according to indirect tensile test at the three test temperatures along with the four loading were used in calculating structural properties ( $\mu, E, E$ and $\sigma)$ of the investigated mixes using the previous equations and their values are listed in Tables $(8,9,10$ and 11$)$, respectively. 


\section{ESTIMATING STRUCTURAL PROPERTIES FROM ROUTINE MIX CHARACTERISTICS}

The values of structural properties presented in Tables (8, 9, 10 and 11) along with the routine characteristics of the investigated mixes, presented in Table (7), were used for developing the mix condition effect models. A multiple regression analysis (SPSS) [14] was performed to determine structural properties $(\mathrm{E}, \sigma, \varepsilon$ and $\mu$ ) from these data. After considering a large number of trial and error solutions, the combination of mix characteristics, which gave the highest correlation $\left(R^{2}\right)$ and lowest standard error $\left(S_{e}\right)$ for $(E, \sigma, \varepsilon$ and $\mu$ ), were selected for case $T 20 \mathrm{R} 05\left(\mathrm{~T}_{0}=20^{\circ} \mathrm{C}\right.$ and $\mathrm{R}_{0}$ $=0.05 \mathrm{in} / \mathrm{min}$ ), with the form:

$$
\begin{aligned}
& E(p s i)=1.58\left(S_{M}\right)-375(\text { VFA })+13400(\Lambda) \\
& +8017(\mathrm{G})+17922(\mathrm{C})-350 \\
& \left(R^{2}=0.99 \text { and } S_{e}=350\right) \\
& \sigma(p s i)=0.0084\left(S_{M}\right)-2(V F A)+70.84(A) \\
& +42.3(\mathrm{G})+96.4(\mathrm{C})-1.8 \\
& \left(R^{2}=0.99 \text { and } S_{\varepsilon}=1.92\right) \\
& \varepsilon\left(\mathbf{X}_{\mathbf{H}}\right)=-0.0001\left(\mathrm{~S}_{\mathrm{M}}\right)+0.013(\mathrm{VFA})-0.22(\mathrm{~A}) \\
& -1.4(\mathrm{G})-1.25(\mathrm{C})+11.5 \\
& \left(R^{2}=0.955 \text { and } S_{e}=0.112\right) \\
& \mu=-6 E-6\left(S_{M}\right)+8.4 E-4(V F A)-0.01(A) \\
& -0.075(\mathrm{G})-0.08(\mathrm{C})+0.37 \\
& \left(R^{2}=0.96 \text { and } S_{e}=0.0065\right)
\end{aligned}
$$

Where:

$\mathrm{E}, \sigma, \varepsilon$ and $\mu$ are the structural propertics at $\mathrm{T}=20^{\circ} \mathrm{C}$ and $\mathrm{R}=0.05 \mathrm{in} / \mathrm{min}$;

VFA $=\%$ voids filled with asphalt;
$\mathrm{A}=$ aggregate factor $(0.8,1.0$ and 1.30 for basalt, dolomite and limestone, respectively);
$\mathrm{G}=$ gradation factor $(0.7,1.0$ and 1.30 for $5 \mathrm{~A}, 4 \mathrm{C}$ and $3 \mathrm{~A}$, respectivcly);
C = compaction factor $(0.7,0.8$ and 1.0 for low, medium and high compaction, respectively); and
$\mathrm{S}_{\mathrm{M}}=$ Marshall stiffness (psi).

\section{DEVELOPMENT OF TEMPERATURE AND LOADING RATE MODEL}

The values of structural properties of the investigated 12 cases of testing conditions presented in Table $(8,9,10$ and 11) were used for developing temperature and loading rate effect models for structural properties. A multiple regression analysis using the SPSS program was performed to determine the investigated structural properties ( $\mathrm{E}, \sigma, \varepsilon$ and $\mu$ ) at the most difficult conditions from those measured at easy conditions. The values of $E, \sigma, \varepsilon$ and $\mu$ measured at $T_{o}=20^{\circ} \mathrm{C}$ and $R_{0}=0.05$ in/min were used as a reference case to predict structural properties (E, $\sigma, \varepsilon$ and $\mu$ ) of the other 11 cases. By combining these cases (each of 20 observations) together, including 220 observations in multiple regression analysis and after several trials to obtain the best fit for the data, the following exponential relationships provide the best fit of the data:

$$
\begin{gathered}
E=E_{0}\left(T / T_{0}\right)^{-2.12}\left(R / R_{0}\right)^{0.196} \\
\left(R^{2}=0.996 \text { and } S_{e}=0.026\right) \\
\sigma=\sigma_{0}\left(T / T_{0}\right)^{-2.56}\left(R / R_{0}\right)^{0.192} \\
\left(R^{2}=0.997 \text { and } S_{e}=0.027\right) \\
\varepsilon=\varepsilon_{0}\left(T / T_{0}\right)^{0.16}\left(R / R_{0}\right)^{-0.016} \\
\left(R^{2}=0.98 \text { and } S_{e}=5.63 E-3\right) \\
\mu=\mu_{0}\left(T / T_{0}\right)^{1.21}\left(R / R_{0}\right)^{-0.06} \\
\left(R^{2}=0.991 \text { and } S_{e}=0.022\right)
\end{gathered}
$$

Where:

$E, \sigma, \varepsilon$ and $\mu$ are the pridicted value of structural properties at $\mathrm{T}$ and $\mathrm{R}$;

$\mathrm{E}_{0,}, \sigma_{o}, \varepsilon_{0}$ and $\mu_{0}$ are the measured values of structural properties at $T_{0}$ and $R_{0 ;} ;$

$\mathrm{T}=$ The actual temperature $\left({ }^{\circ} \mathrm{C}\right)$;

$\mathrm{T}_{a}=$ The room temperature $\left({ }^{\circ} \mathrm{C}\right)$;

$R=$ The actual loading rate(in/min);

$R_{0}=$ The loading rate considered in the test (in/min). 
The developed relations can be used to determine the values of $E, \sigma, \varepsilon$ and $\mu$ of asphalt concrete at any $T$ and $R$ by conducting indirect tensile test at room temperature $\left(\mathrm{T}_{0}\right)$ at $\left(\mathrm{R}_{0}=0.05 \mathrm{in} / \mathrm{min}\right)$. The existence of these relations is checked statistically using the F- test. The $F_{\text {Comp. }}$ is 60 and the corresponding $F_{\text {Crit. }}$ value at a significant level $a=0.01$ and degree of freedom 2, $(\mathrm{n}-1-2=217)$ is $4.61(\mathrm{n}=$ number of observations $=220$ ). Since $F_{\text {Comp }}$ is greater than $F_{C r i}$, the relation exists at the chosen significant level.

For more simplification, each pairs of the four developed models were combined together into one general model for predicting structural properties $(\mathrm{E}, \sigma, \varepsilon$ and $\mu$ ) of paving mixes based on routine mix characteristics, temperature and rate of loading. By substituting $T_{0}=20^{\circ} \mathrm{C}$ and $R_{0}=$ $0.05 \mathrm{in} / \mathrm{min}$ for T20R05 case, the following exponential relations were suggested:

$$
\begin{aligned}
& E=1031\left(T ^ { - 2 . 1 2 } ( R ) ^ { 0 . 1 9 6 } \left(1.58\left(S_{M}\right)-375(V F A)+\right.\right. \\
& 13400(A)+8017(\mathrm{G})+17922(\mathrm{C})-350\} \\
& \sigma=3806(T)^{-2.5}(R)^{0192}\left\{0.0084\left(S_{M}\right)-2(V F A)+\right. \\
& 70.84(\mathrm{~A})+42.3(\mathrm{G})+96.4(\mathrm{C})-1.8\} \\
& \varepsilon=0.56\left(T ^ { 0 . 3 6 } ( \mathrm { R } ) ^ { - 0 . 0 3 6 } \left\{-10^{-4}\left(\mathrm{~S}_{\mathrm{M}}\right)+0.013(\mathrm{VFA})-\right.\right. \\
& 0.22(\mathrm{~A})-1.4(\mathrm{G})-1.25(\mathrm{C})+11.5\} \\
& \mu=0.022(T)^{1.21}(R)^{-0.06}\left\{-6 E-6\left(S_{M}\right)+8.4 E-4(V F A)-\right. \\
& 0.01(\mathrm{~A})-0.075(\mathrm{G})-0.08(\mathrm{C})+0.37)
\end{aligned}
$$

These models were developed based on the asphalt mixes all using the same asphalt $60 / 70$ binder. Applicability of this models should be further validated with asphait mixes using different grades of asphalt binders. The predicted values of structural properties ( $E, \sigma, \varepsilon$ and $\mu$ ) using the developed models are presented in Tables (12, 13, 14 and 15) respectively. Comparing the predicted values of structural properties using the developed models with the measured ones, it can be seen that the predicted values slightly deviate from the measured values. Only 20,22, 27 and 2 out of 240 predicted values deviated by more than $5 \%$ for $E, \mu, \sigma$ and $E$, respectively with the maximum deviation of $11 \%$.

\section{CONCLUSIONS}

Based on the methodology and analysis of results of this study, the following conclusions were drawn:

1. The expected structural properties (E, $\sigma$, $\varepsilon$ and $\mu$ ) of asphalt layer at any field condition of temperature and loading rate can be predicted with good accuracy using the developed relations.

2. Elasticity modulus values decrease by a factor of 0.23 and 0.10 , while tensile strength values decrease by a factor of 0.17 and 0.06 as the temperature increases from 20 to $40^{\circ} \mathrm{C}$ and from 20 to $60^{\circ} \mathrm{C}$, respectively.

3. Poisson's ratio values increase by a factor of 2.3 and 3.78 , while tensile strain values increase by a factor of 1.12 and 1.20 as the temperature increases from 20 to $40^{\circ} \mathrm{C}$ and from 20 to $60^{\circ} \mathrm{C}$, respectively.

4. Both elasticity modulus and tensile strength values increase by a factor of approximatcly 2.0 as the loading rate increases from 0.05 to $2 \mathrm{in} / \mathrm{min}$.

5. Poisson's ratio values decrease by a factor of 0.8 , while tensile strain values decrease by a factor of 0.9 as the loading rate increases from 0.05 to $2 \mathrm{in} / \mathrm{min}$.

6. Increasing asphatt content by $1 \%$ above OAC leads to decreasing elasticity modulus and tensile strength by a factor of 0.65 , whife decreasing it by $1 \%$ leads to increasing them by a factor of 1.30 .

7. Both elasticity modulus and tensile strength of paving mixes containing limestone and basalt were found to be 
about 1.30 and 0.80 times that containing dolomitc, respectively.

8. Mixes containing crushed sand as fine portion exhibit elasticity modulii and tensile strength values $20 \%$ higher than that containing natural sand.

9. Mixes containing basalt (as coarse portion) and crushed sand (as fine portion) exhibit elasticity modulii and tensile strength $5 \%$ higher than that containing dolomitc and natural sand.

10. Elasticity modulus and tensile strength of paving mixes using $3 \mathrm{~A}$ gradation was found to be about 1.30 and 1.85 times that using $4 \mathrm{C}$ and $5 \mathrm{~B}$ gradations, respectively.

11. Elasticity modulus and tensile strength of paving mixes at medium and low compactive efforts were found to be about 0.80 and 0.70 times that at high compactive efforts, respectively.

12. Aggregate types and gradation, asphalt conent and compactive effort slightly affect Poisson's ratio and tensile strain.

\section{REFERENCES}

1. "AASHTO Interim Guid for Design of Pavement Structures," American Association for State Highway and Transportation Officials, 1979, Chapter III (revised), 1981.

2. Baladi, G. Y., "Characterization of Flexible Pavement; A Case Study," Properties of Flexible Materials, ASTM STP 807, Philadelphia, 1983, pp 164-7I.

3. Baladi, G. Y., and Harichandran, R. S.,“ Asphalt Mix Design and the Indirect Test: A New Horizon," Asphalt Concrete Mix Design: Development of More Rational Approaches, ASTM STP 1041, Philadelphia, 1989, pp. 86-105.

4. Finn, F. N., "Factors Involved in the Design of Asphaltic pavement Surfaces," National Cooperative
Highway Research Program No. 39, 1967, pp. 1-112.

5. Yoder, E. J., and Witczak, M. W., "Pricipals of Pavement Design, $2^{\text {nd }}$ ed., Wiley, New York, 1975.

6. "Asphalt Overlays for Highway and Street Rehabilitation," The Asphalt Institute, Manual Series No. 17 (MS-17), June 1983.

7. Kennedy, T. W., "Characterization of Asphalt Pavement Materials using the Indirect Tensilc Test", Proceedings, AAPT, Vol. 46, Feb. 1977, pp. 132-149.

8. Kennedy, T. W., "Tensile and Elastic Characteistics of Black-Base Materials", HRB, Highway Transportation Record 510,1974 , pp. 31- 40 .

9. Maupin, G. W., jr. " Results of Indirect Tests Related to Asphalt Fatigue", HRB, Highway Ressearch Record 404, 1972 , pp.1-7.

10. Anderson, K. O, and Hahan, W, O., "Design and Evaluation of Asphalt Concrete with Respect to thermal Cracking", Proceedings, AAPT, Vol. 37, Fcb. 1968, pp. 1-31.

11. Mekkawi, A. H., "Effect of Sulpher on Road Paving Mixtures using Low Cost Aggregates", Ph. D. Thesis, Faculty of Eng., Cairo University, 1992.

12. Abdel-Motaleb, M. E., "Effect of Mixing Technology on Hot Asphaltic Mixtures Properties", M. Sc. Thesis Faculty of Eng., Zagazig Univ,, 1996.

13. Abdel-Motaleb, M. E., and Mohamady, A., "A Simplified Technique for Measuring Dynamic Modulus of Aphalt Concrete", Mansura Engineering Joumal, Volume 29, No. 3, September 2004, Mansura, Egypt.

14. Statistical Package for Social Science under Windows "SPSS win" Program, Ver. 7.5.2, May 1997. 
Table 1: Gradations of the Investigated Mixes

\begin{tabular}{|l|c|c|c|c|c|c|}
\hline \multirow{2}{*}{$\begin{array}{c}\text { Sicve } \\
\text { Size }\end{array}$} & \multicolumn{3}{|c|}{ Designed Gradation } & \multicolumn{3}{c|}{ Specification Limits } \\
\cline { 2 - 7 } & $3 \mathrm{~A}$ & $4 \mathrm{C}$ & $5 \mathrm{~B}$ & $3 \mathrm{~A}$ & $4 \mathrm{C}$ & $5 \mathrm{~B}$ \\
\hline 1 in & 100 & 100 & 100 & 100 & 100 & 100 \\
$3 / 4$ in & 100 & 90 & 100 & 100 & $80-100$ & 100 \\
$1 / 2$ in & 100 & 80 & 92 & 100 & - & $85-100$ \\
$3 / 8$ in & 88 & 70 & 85 & $75-100$ & $60-80$ & - \\
No. 4 & 45 & 56 & 73 & $35-55$ & $48-65$ & $65-80$ \\
No. 8 & 28 & 43 & 58 & $20-35$ & $35-50$ & $50-65$ \\
No.16 & 20 & 30 & 45 & - & - & $37-52$ \\
No.30 & 16 & 24 & 33 & $10-22$ & $19-30$ & $25-40$ \\
No. 50 & 11 & 18 & 24 & $6-16$ & $13-23$ & $18-30$ \\
No. 100 & 8 & 11 & 15 & $4-12$ & $7-15$ & $10-20$ \\
No. 200 & 5 & 5.5 & 6.5 & $2-8$ & $3-8$ & $3-10$ \\
\hline
\end{tabular}

Table 2: Mix Variables used in the Study

\begin{tabular}{|c|c|c|c|c|c|c|c|c|c|c|c|c|c|c|}
\hline \multirow{2}{*}{$\begin{array}{c}\mathrm{Mi}_{\mathrm{i}} \\
\mathrm{N} \\
\mathrm{No}\end{array}$} & \multicolumn{3}{|c|}{ Coarse Aggr. Type } & \multicolumn{2}{|c|}{ Sand type } & \multicolumn{3}{|c|}{ Gradation } & \multicolumn{3}{|c|}{$\begin{array}{c}\text { Asphalt Content } \\
(\%)\end{array}$} & \multicolumn{3}{|c|}{$\begin{array}{c}\text { Compaction Effort } \\
\text { (blows) }\end{array}$} \\
\hline & D & L & B & NS & $\mathrm{CS}$ & $4 \mathrm{C}$ & $3 \mathrm{~A}$ & $5 B$ & $\begin{array}{l}\text { OAC } \\
-1 \%\end{array}$ & $\mathrm{OAC}$ & $\begin{array}{l}\text { OAC } \\
+1 \%\end{array}$ & 35 & 50 & 75 \\
\hline 1 & $*$ & & & * & & + & & & - & & & & & 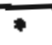 \\
\hline 2 & 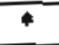 & & & 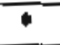 & & - & & & & $*$ & & & & 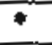 \\
\hline 3 & 4 & & & $\%$ & & * & & & & & - & & & $\cdot$ \\
\hline 4 & & - & & *- & & 7 & & & $\div$ & & & & & 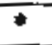 \\
\hline 5 & & - & & . & & * & & & & * & & 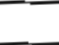 & 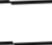 & $*$ \\
\hline 6 & & $\%$ & & - & & 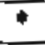 & & & & & 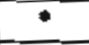 & & 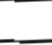 & 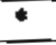 \\
\hline 7 & & & * & -7 & & 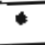 & & & * & & & & 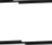 & 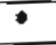 \\
\hline 8 & & & 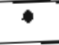 & * & & * & & & & * & & & & 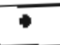 \\
\hline 9 & & & - & 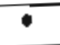 & & - & & & & & - & & 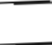 & 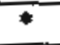 \\
\hline 10 & - & & & & * & - & & & & - & & & & * \\
\hline II & & - & & & 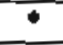 & $*$ & & & & - & - & & & -7 \\
\hline 12 & & & * & & $\div$ & * & & & & 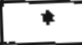 & & 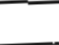 & 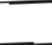 & $*$ \\
\hline 13 & 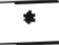 & & & - & & & $*$ & & & $*$ & & & & - \\
\hline 14 & * & & & $*$ & & & & $*$ & & * & & & & $\div$ \\
\hline 15 & 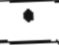 & & & $*$ & & * & & & & $*$ & & & - & \\
\hline 16 & - & & & $\cdot$ & & * & & & & . & & 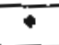 & & \\
\hline 17 & * & & & * & & & * & & & . & & & 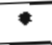 & \\
\hline 18 & - & & & $\div$ & & & 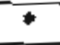 & & & 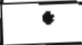 & & * & & \\
\hline 19 & $*$ & & & - & & & & 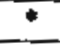 & & $\div$ & & & 7 & \\
\hline 20 & $*$ & & & * & & & & - & & $*$ & & $\div$ & & \\
\hline
\end{tabular}

Notes: $D=$ Dolomite,$L=$ Limestone, $B=$ Basalt $N S=$ Natural Sand, $C S=$ Crushed Sand 
C. 111 Mohamed Elsaid Abdel-Motaleb

Table 3: Cases of Testing Conditions for Temperatures (T) and Rate of Londing (R)

\begin{tabular}{|c|c|c|c|c|c|c|c|c|c|c|c|c|}
\hline $\mathrm{T}\left({ }^{\circ} \mathrm{C}\right)$ & \multicolumn{3}{|c|}{$\mathrm{T}=20^{\circ} \mathrm{C}$} & \multicolumn{3}{c|}{$\mathrm{T}=40^{\circ} \mathrm{C}$} & \multicolumn{3}{c|}{$\mathrm{T}=60^{\circ} \mathrm{C}$} \\
\hline $\mathrm{R}$ (in/min) & $\mathrm{R}=$ & $\mathrm{R}=$ & $\mathrm{R}=$ & $\mathrm{R}=$ & $\mathrm{R}=$ & $\mathrm{R}=$ & $\mathrm{R}=$ & $\mathrm{R}=$ & $\mathrm{R}=$ & $\mathrm{R}=$ & $\mathrm{R}=$ & $\mathrm{R}=$ \\
& 0.05 & 0.50 & 1.00 & 2.00 & 0.05 & 0.50 & 1.00 & 2.00 & 0.05 & 0.50 & 1.00 & 2.00 \\
\hline Case & $\mathrm{T} 20 \mathrm{R} 05$ & $\mathrm{~T} 20 \mathrm{R} 0.5$ & $\mathrm{~T} 20 \mathrm{R} 1$ & $\mathrm{~T} 20 \mathrm{R} 2$ & $\mathrm{~T} 40 \mathrm{R} 05$ & $\mathrm{~T} 40 \mathrm{R} 0.5$ & $\mathrm{~T} 40 \mathrm{R} 1$ & $\mathrm{~T} 40 \mathrm{R} 2$ & $\mathrm{~T} 60 \mathrm{R} 05$ & $\mathrm{~T} 60 \mathrm{R} 0.5$ & $\mathrm{~T} 60 \mathrm{R} 1$ & $\mathrm{~T} 60 \mathrm{~N} 2$ \\
\hline
\end{tabular}

Table 4: Properties of Coarse Aggregate Materials

\begin{tabular}{|c|c|c|c|c|c|c|}
\hline \multirow{2}{*}{$\begin{array}{l}\text { Test } \\
\text { No. }\end{array}$} & \multirow[b]{2}{*}{ Test } & \multirow{2}{*}{$\begin{array}{c}\text { AASHTO } \\
\text { Designation No. }\end{array}$} & \multicolumn{3}{|c|}{ Results } & \multirow{2}{*}{$\begin{array}{c}\text { Specification } \\
\text { Limils }\end{array}$} \\
\hline & & & Dolomite & Limestone & Basalt & \\
\hline \multirow[t]{4}{*}{1} & Specific gravity (S.G); & $\mathrm{T}-85$ & & & & \\
\hline & -Bulk S.G & & 2.512 & 2.285 & 2.782 & - \\
\hline & -Saturated surface-dry S.G & & 2.539 & 2.413 & 2.836 & - \\
\hline & -Apparent S.G & & 2.659 & $2.60 \mathrm{~J}$ & 2.958 & - \\
\hline 2 & Waler absorption (\%) & $\mathrm{T}-85$ & 2.61 & 4.75 & 2.12 & $\leq 5$ \\
\hline 3 & Disintegration (\%) & $T-112$ & 0.63 & 0.90 & 0.54 & $\leq 1$ \\
\hline 4 & Los Angeles Abrasion; & $T-96$ & & & & \\
\hline & -After 100 rev. $(\%)$ & & 5.6 & 9.3 & 4.8 & $\leq 10$ \\
\hline & -After 500 rev. $(\%)$ & & 24 & 38 & 20 & $\leq 40$ \\
\hline 5 & Stripping (\%) & $T-182$ & $>95$ & $>95$ & $>95$ & $\geq 95$ \\
\hline
\end{tabular}

Table 5: Gradations of Fine Materials

\begin{tabular}{|l|c|c|c|c|}
\hline \multicolumn{1}{|c|}{ Sieve } & \multicolumn{3}{|c|}{ Percent Passing } & Specification Limits \\
\cline { 2 - 4 } Size & Natural Sand & Crushed Sand & Mineral Filler & \\
\hline No. 4 & 100 & 100 & & \\
No. 8 & 95 & 96 & & \\
No. 16 & 84 & 85 & & \\
No. 30 & 64 & 63 & 100 & 100 \\
No. 50 & 21 & 22 & 95 & - \\
No. 100 & 3.3 & 2.9 & 88 & $\geq 85$ \\
No. 200 & 1.5 & 1.3 & 70 & $\geq 65$ \\
\hline
\end{tabular}


Table 6: Properties of Bituminous Material

\begin{tabular}{|c|l|c|c|c|}
\hline $\begin{array}{c}\text { Test } \\
\text { No. }\end{array}$ & \multicolumn{1}{|c|}{ Test } & $\begin{array}{c}\text { AASHTO } \\
\text { Designation No. }\end{array}$ & $\begin{array}{c}\text { Results of } \\
\text { AC } 60 / 70\end{array}$ & $\begin{array}{c}\text { Specificalion } \\
\text { Limits of AC 60/70 }\end{array}$ \\
\hline 1 & Penetration (at $25^{\circ} \mathrm{C}$, $0.1 \mathrm{~mm}$ & $\mathrm{~T}-49$ & 63 & $60-70$ \\
2 & Softening point, ${ }^{\circ} \mathrm{C}$ & $\mathrm{T}-53$ & 52 & $45-55$ \\
3 & Flash point, ${ }^{\circ} \mathrm{C}$ & $\mathrm{T}-48$ & +270 & $\geq 250$ \\
4 & Kinematic Viscosity.(at $135^{\circ} \mathrm{C}$ ), Cst & $\mathrm{T}-72$ & 353 & $\geq 320$ \\
\hline
\end{tabular}

Table 7: Routine Characteristics of the Investigated Mixes

\begin{tabular}{|c|c|c|c|c|c|c|c|c|}
\hline $\begin{array}{c}\text { Mix } \\
\text { No. }\end{array}$ & AC (\%) & AV (\%) & $\begin{array}{c}\text { VMA } \\
(\%)\end{array}$ & $\begin{array}{c}\text { VFA } \\
(\%)\end{array}$ & $\begin{array}{c}\text { Unit weight } \\
\left(\mathrm{gm} / \mathrm{cm}^{3}\right)\end{array}$ & $\begin{array}{c}\text { Stability } \\
\text { (lb) }\end{array}$ & $\begin{array}{c}\text { Flow } \\
\text { in) }\end{array}$ & $\begin{array}{c}\mathrm{S}_{\mathrm{M}} \\
\text { (psi) }\end{array}$ \\
\hline 1 & 4.5 & 5.70 & 15.60 & 63.9 & 2.312 & 1966 & 9.25 & 8502 \\
\hline 2 & 5.5 & 3.50 & 15.50 & 77.9 & 2.331 & 2171 & 10.50 & 8270 \\
\hline 3 & 6.5 & 1.80 & 17.00 & 88.9 & 2.362 & 1782 & 12.50 & 5702 \\
\hline 4 & 5.6 & 6.40 & 18.30 & 61.3 & 2.212 & 2453 & 9.00 & 10902 \\
\hline 5 & 6.6 & 4.00 & 17.70 & 77.5 & 2.252 & 2583 & 10.25 & 10080 \\
\hline 6 & 7.6 & 2.00 & 19.10 & 89.5 & 2.273 & 2171 & 13.00 & 6680 \\
\hline 7 & 4.0 & 6.30 & 15.50 & 62.8 & 2.423 & 1461 & 9.50 & 6150 \\
\hline 8 & 5.0 & 3.70 & 15.10 & 75.5 & 2.462 & 1611 & 11.50 & 5602 \\
\hline 9 & 6.0 & 1.90 & 16.60 & 83.5 & 2.472 & 1831 & 14.00 & 5230 \\
\hline 10 & 5.5 & 3.60 & 15.60 & 76.9 & 2.325 & 2402 & 10.00 & 9607 \\
\hline 11 & 6.6 & 4.10 & 17.85 & 74.4 & 2.244 & 2927 & 10.50 & 11150 \\
\hline 12 & 5.0 & 3.70 & 15.25 & 70.1 & 2.455 & 2311 & 10.75 & 8600 \\
\hline 13 & 5.2 & 4.20 & 16.65 & 73.8 & 2.312 & 2351 & 9.50 & 9898 \\
\hline 14 & 6.2 & 3.10 & 14.50 & 82.5 & 2.363 & 2174 & 12.25 & 7100 \\
\hline 15 & 5.5 & 3.70 & 15.60 & 76.3 & 2.325 & 2162 & 11.00 & 7860 \\
\hline 16 & 5.5 & 4.10 & 16.00 & 74.2 & 2.323 & 1909 & 11.75 & 6500 \\
\hline 17 & 5.2 & 4.50 & 18.00 & 75.0 & 2.300 & 2582 & 10.75 & 9607 \\
\hline 18 & 5.2 & 5.00 & 18.50 & 73.0 & 2.272 & 2251 & 12.25 & 7350 \\
\hline 19 & 6.2 & 3.25 & 15.25 & 78.1 & 2.301 & 2007 & 11.50 & 6980 \\
\hline 20 & 6.2 & 3.40 & 15.50 & 76.5 & 2.252 & 1823 & 12.75 & 5720 \\
\hline
\end{tabular}

Note: * OAC, obtained from Standard Marshall Design Mcthou.

$\mathrm{S}_{\mathrm{M}}=$ Marshall Stiffness $=$ Stability $/($ Flow $*$ Specimen Height $)$ 
C. 113 Mohamed Elsaid Abdel-Motaleb

Table 8: Measured Values of $\mu$ for the Investigated Mires at Dilferent $T$ and $R$

\begin{tabular}{|c|c|c|c|c|c|c|c|c|c|c|c|c|}
\hline \multirow[b]{2}{*}{$\begin{array}{c}\text { Mix } \\
\text { No }\end{array}$} & \multicolumn{4}{|c|}{$T=20^{\circ} \mathrm{C}$} & \multicolumn{4}{|c|}{$\mathrm{T}=40^{\circ} \mathrm{C}$} & \multicolumn{4}{|c|}{$T=60^{\circ} \mathrm{C}$} \\
\hline & $\begin{array}{l}R= \\
0.05\end{array}$ & $\begin{array}{l}R= \\
0.50\end{array}$ & $\begin{array}{l}\mathrm{R}= \\
1.00\end{array}$ & $\begin{array}{l}\mathrm{R}= \\
2.00\end{array}$ & $\begin{array}{l}\mathrm{R}= \\
0.05\end{array}$ & $\begin{array}{l}\mathrm{R}= \\
0.50\end{array}$ & $\begin{array}{l}\mathrm{R}= \\
1.00\end{array}$ & $\begin{array}{l}R= \\
2.00\end{array}$ & $\begin{array}{l}R= \\
0.05 \\
\end{array}$ & $\begin{array}{l}\mathrm{R}= \\
0.50\end{array}$ & $\begin{array}{l}R= \\
1.00\end{array}$ & $\begin{array}{l}R= \\
2.00\end{array}$ \\
\hline 1 & 0.20 & 0.17 & 0.15 & 0.14 & 0.45 & 0.40 & 0.37 & 0.36 & 0.70 & 0.64 & $\overline{0.60}$ & 0.58 \\
\hline 2 & 0.21 & 0.18 & 0.16 & 0.15 & 0.47 & 0.42 & 0.39 & 0.37 & 0.73 & 0.66 & 0.62 & 0.60 \\
\hline 3 & 0.25 & 0.21 & 0.19 & 0.18 & 0.52 & 0.47 & 0.44 & 0.42 & 0.81 & 0.73 & 0.69 & 0.67 \\
\hline 4 & 0.19 & 0.16 & 0.14 & 0.13 & 0.44 & 0.39 & 0.36 & 0.35 & 0.69 & 0.62 & 0.59 & 0.57 \\
\hline 5 & 0.20 & 0.17 & 0.15 & 0.14 & 0.45 & 0.40 & 0.37 & 0.36 & 0.71 & 0.64 & 0.60 & 0.58 \\
\hline 6 & 0.23 & 0.19 & 0.17 & 0.16 & 0.49 & 0.44 & 0.41 & 0.39 & 0.77 & 0.69 & 0.65 & 0.63 \\
\hline 7 & 0.21 & 0.18 & 0.16 & 0.15 & 0.47 & 0.42 & 0.39 & 0.37 & 0.73 & 0.66 & 0.62 & 0.60 \\
\hline 8 & 0.23 & 0.20 & 0.18 & 0.17 & 0.50 & 0.44 & 0.41 & 0.40 & 0.77 & 0.70 & 0.66 & 0.64 \\
\hline 9 & 0.24 & 0.21 & 0.19 & 0.18 & 0.52 & 0.46 & 0.43 & 0.41 & 0.80 & 0.72 & 0.68 & 0.66 \\
\hline 10 & 0.20 & 0.17 & 0.15 & 0.14 & 0.45 & 0.40 & 0.37 & 0.36 & 0.70 & 0.64 & 0.60 & 0.58 \\
\hline 11 & 0.18 & 0.15 & 0.13 & 0.13 & 0.43 & 0.38 & 0.35 & 0.34 & 0.67 & 0.61 & 0.57 & 0.55 \\
\hline 12 & 0.21 & 0.18 & 0.16 & 0.15 & 0.47 & 0.42 & 0.39 & 0.37 & 0.73 & 0.66 & 0.62 & 0.60 \\
\hline 13 & 0.18 & 0.15 & 0.13 & 0.13 & 0.43 & 0.38 & 0.35 & 0.34 & 0.67 & 0.61 & 0.57 & 0.55 \\
\hline 14 & 0.26 & 0.22 & 0.20 & 0.19 & 0.54 & 0.48 & 0.45 & 0.43 & 0.83 & 0.75 & 0.71 & 0.68 \\
\hline 15 & 0.23 & 0.19 & 0.17 & 0.16 & 0.49 & 0.44 & 0.41 & 0.39 & 0.77 & 0.69 & 0.65 & 0.63 \\
\hline 16 & 0.24 & 0.21 & 0.19 & 0.18 & 0.52 & 0.46 & 0.43 & 0.41 & 0.80 & 0.72 & 0.68 & 0.66 \\
\hline 17 & 0.20 & 0.17 & 0.15 & 0.14 & 0.45 & 0.40 & 0.37 & 0.36 & 0.70 & 0.64 & 0.60 & 0.58 \\
\hline 18 & 0.21 & 0.18 & 0.16 & 0.15 & 0.47 & 0.42 & 0.39 & 0.37 & 0.73 & 0.66 & 0.62 & 0.60 \\
\hline 19 & 0.26 & 0.23 & 0.20 & 0.19 & 0.55 & 0.49 & 0.46 & 0.44 & 0.84 & 0.76 & 0.72 & 0.69 \\
\hline 20 & 0.29 & 0.25 & 0.23 & 0.21 & 0.58 & 0.52 & 0.49 & 0.47 & 0.89 & 0.81 & 0.76 & 0.74 \\
\hline
\end{tabular}

Table 9: Measured Values of $\mathrm{E}$ (psi) for the Investigaled Mixes at Different $\mathrm{T}$ and $\mathrm{R}$

\begin{tabular}{|c|c|c|c|c|c|c|c|c|c|c|c|c|}
\hline \multirow{2}{*}{$\begin{array}{c}\text { Mix } \\
\text { No }\end{array}$} & \multicolumn{3}{|c|}{$\mathrm{T}=20^{\circ} \mathrm{C}$} & \multicolumn{3}{|c|}{$\mathrm{T}=40^{\circ} \mathrm{C}$} & \multicolumn{3}{|c|}{$\mathrm{T}=60^{\circ} \mathrm{C}$} \\
& 0.05 & $\mathrm{R}=$ & $\mathrm{R}=$ & $\mathrm{R}=$ & $\mathrm{R}=$ & $\mathrm{R}=$ & $\mathrm{R}=$ & $\mathrm{R}=$ & $\mathrm{R}=$ & $\mathrm{R}=$ & $\mathrm{R}=$ & $\mathrm{R}=$ \\
1.00 & 2.00 & 0.05 & 0.50 & 1.00 & 2.00 & 0.05 & 0.50 & 1.00 & 2.00 \\
\hline 1 & 28267 & 44287 & 50697 & 58034 & 6548 & 10259 & 11744 & 13443 & 2783 & 4361 & 4992 & 5714 \\
\hline 2 & 22730 & 35020 & 41200 & 46800 & 5020 & 8050 & 9300 & 10600 & 2020 & 3600 & 4100 & 4750 \\
\hline 3 & 14973 & 23459 & 26854 & 30740 & 3468 & 5434 & 6221 & 7121 & 1500 & 2310 & 2644 & 3027 \\
\hline 4 & 37709 & 60001 & 66700 & 78411 & 8600 & 12686 & 14700 & 17100 & 3820 & 6000 & 6800 & 7800 \\
\hline 5 & 29279 & 45873 & 52512 & 59010 & 6782 & 10626 & 12164 & 12900 & 2850 & 4517 & 5250 & 6010 \\
\hline 6 & 20004 & 31300 & 36100 & 41070 & 4200 & 7100 & 8200 & 9514 & 1870 & 3200 & 3560 & 4100 \\
\hline 7 & 22149 & 34702 & 39724 & 44570 & 5131 & 8039 & 9202 & 9500 & 2000 & 3417 & 3911 & 4477 \\
\hline 8 & 16836 & 26450 & 31100 & 34565 & 3750 & 5850 & 6800 & 7850 & 1700 & 2700 & 3200 & 3500 \\
\hline 9 & 13446 & 21200 & 24115 & 28010 & 3115 & 4880 & 5586 & 6395 & 1260 & 2074 & 2374 & 2718 \\
\hline 10 & 25635 & 40163 & 45500 & 52629 & 5750 & 9100 & 10450 & 11500 & 2524 & 4200 & 4650 & 5210 \\
\hline 11 & 32859 & 51550 & 58500 & 68200 & 7450 & 11926 & 13652 & 14600 & 3150 & 5069 & 5803 & 6642 \\
\hline 12 & 23780 & 37257 & 42649 & 49100 & 4800 & 8350 & 9680 & 11309 & 2240 & 3680 & 4300 & 4900 \\
\hline 13 & 29590 & 47001 & 52600 & 59500 & 6854 & 10739 & 12293 & 13500 & 3010 & 4565 & 5300 & 5982 \\
\hline 14 & 16345 & 25700 & 29315 & 32100 & 3650 & 5701 & 6501 & 7773 & 1609 & 2700 & 2886 & 3304 \\
\hline 15 & 19320 & 31000 & 35500 & 38900 & 4475 & 7012 & 8027 & 8200 & 2000 & 3050 & 3550 & 4010 \\
\hline 16 & 16408 & 25708 & 30100 & 33687 & 3650 & 5760 & 6616 & 7605 & 1616 & 2531 & 2898 & 3450 \\
\hline 17 & 24446 & 39001 & 43843 & 49500 & 5663 & 8672 & 10156 & 11626 & 2650 & 3850 & 4550 & 4942 \\
\hline 18 & 20001 & 31337 & 36500 & 41063 & 4450 & 7259 & 8120 & 9300 & 2010 & 3086 & 3600 & 4015 \\
\hline 19 & 14699 & 24100 & 26363 & 31200 & 3405 & 5200 & 5950 & 6991 & 1447 & 2380 & 2596 & 3010 \\
\hline 20 & 11673 & 18288 & 21500 & 23964 & 2600 & 4210 & 4849 & 5200 & 1250 & 1801 & 2150 & 2405 \\
\hline
\end{tabular}




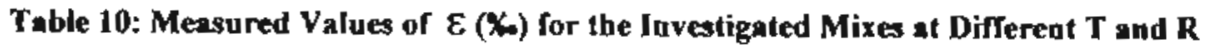

\begin{tabular}{|c|c|c|c|c|c|c|c|c|c|c|c|c|}
\hline \multirow{2}{*}{$\begin{array}{l}\text { Mix } \\
\text { No }\end{array}$} & \multicolumn{4}{|c|}{$\mathrm{T}=20^{\circ} \mathrm{C}$} & \multicolumn{4}{|c|}{$\mathrm{T}=40^{\circ} \mathrm{C}$} & \multicolumn{4}{|c|}{$T=60^{\circ} \mathrm{C}$} \\
\hline & $\begin{array}{l}R= \\
0.05\end{array}$ & $\begin{array}{l}\mathrm{R}= \\
0.50 \\
\end{array}$ & $\begin{array}{l}\mathrm{R}= \\
1.00\end{array}$ & $\begin{array}{l}R= \\
2.00\end{array}$ & $\begin{array}{l}R= \\
0.05\end{array}$ & $\begin{array}{l}\mathrm{R}= \\
0.50\end{array}$ & $\begin{array}{l}R= \\
\mathrm{I} .00\end{array}$ & $\begin{array}{l}\mathrm{R}= \\
2.00\end{array}$ & $\begin{array}{l}R= \\
0.05\end{array}$ & $\begin{array}{l}\mathrm{R}= \\
0.50\end{array}$ & $\begin{array}{l}\mathrm{R}= \\
1.00\end{array}$ & $\begin{array}{l}R= \\
2.00\end{array}$ \\
\hline 1 & 8.6 & 8.0 & 7.7 & 7.6 & 9.7 & 9.1 & 8.7 & 8.5 & 10.2 & 9.5 & 9.2 & 9.0 \\
\hline 2 & 8.8 & 8.3 & 7.9 & 7.8 & 10.0 & 9.3 & 9.0 & 8.8 & 10.5 & 9.8 & 9.4 & 9.2 \\
\hline 3 & 9.4 & 8.8 & 8.4 & 8.3 & 10.7 & 10.0 & 9.6 & 9.4 & 11.2 & 10.5 & $10 . \overline{1}$ & 9.9 \\
\hline 4 & 8.5 & 7.9 & 7.6 & 7.5 & 9.6 & 9.0 & $\overline{8.6}$ & 8.4 & 10.1 & 9.4 & 9.0 & 8.9 \\
\hline 5 & 8.6 & 8.1 & 7.8 & 7.6 & 9.8 & 9.1 & 8.8 & 8.6 & 10.3 & 9.6 & 9.2 & 9.0 \\
\hline 6 & 9.0 & 8.5 & 8.2 & 8.0 & 10.3 & 9.6 & 9.2 & 9.0 & 10.8 & 10.1 & 9.7 & 9.5 \\
\hline 7 & 8.8 & 8.3 & 7.9 & 7.8 & 10.0 & 9.3 & 9.0 & 8.8 & $10 . \overline{5}$ & 9.8 & 9.4 & 9.2 \\
\hline 8 & 9.1 & 8.5 & 8.2 & 8.0 & 10.3 & 9.7 & 9.3 & 9.1 & 10.9 & 10.2 & 9.7 & $\overline{9.5}$ \\
\hline 9 & 9.3 & 8.7 & 8.4 & 8.2 & 10.6 & 9.9 & 9.5 & 9.3 & 11.1 & 10.4 & 10.0 & 9.7 \\
\hline 10 & 8.6 & 8.0 & 7.7 & 7.6 & 9.7 & 9.1 & 8.7 & 8.5 & 10.2 & 9.5 & 9.2 & 9.0 \\
\hline 11 & 8.3 & 7.8 & 7.5 & 7.4 & 9.4 & 8.8 & 8.5 & 83 & 9.9 & 9.3 & 8.9 & 8.7 \\
\hline 12 & 8.8 & 8.3 & 7.9 & 7.8 & 10.0 & 9.3 & 9.0 & 8.8 & 10.5 & 9.8 & 9.4 & 9.2 \\
\hline 13 & 8.3 & 7.8 & 7.5 & 7.4 & 9.4 & 8.8 & 8.5 & 8.3 & 9.9 & 9.3 & 8.9 & 8.7 \\
\hline 14 & 9.5 & 8.9 & 8.6 & 8.4 & 10.8 & 10.1 & 9.7 & 9.5 & 11.4 & 10.7 & 10.2 & 10.0 \\
\hline 15 & 9.0 & 8.5 & 8.2 & 8.0 & 10.3 & 9.6 & 9.2 & 9.0 & 10.8 & 10.1 & 9.7 & 9.5 \\
\hline 16 & 9.3 & 8.7 & 8.4 & 8.2 & 10.6 & 9.9 & 9.5 & 9.3 & 11.1 & 10.4 & 10.0 & 9.7 \\
\hline 17 & 8.6 & 8.0 & 7.7 & 7.6 & 9.7 & 9.1 & 8.7 & 8.5 & 10.2 & 9.5 & 9.2 & 9.0 \\
\hline 18 & 8.8 & 8.3 & 7.9 & 7.8 & 10.0 & 9.3 & 9.0 & 8.8 & 10.5 & 9.8 & $9 . \overline{4}$ & 9.2 \\
\hline 19 & 9.6 & 9.0 & 8.7 & 8.5 & 10.9 & 10.2 & 9.8 & $9 . \overline{6}$ & 11.5 & 10.8 & 10.3 & 10.1 \\
\hline 20 & 10.0 & 9.4 & 9.0 & 8.8 & 11.4 & 10.6 & 10.2 & 10.0 & 12.0 & 11.2 & 10.8 & 10.5 \\
\hline
\end{tabular}

Table 11: Measured Values of $\sigma$ (psi) for the Investigated Mixes at Different $T$ and $R$

\begin{tabular}{|c|c|c|c|c|c|c|c|c|c|c|c|c|}
\hline \multirow{2}{*}{$\begin{array}{l}\text { Mix } \\
\text { No }\end{array}$} & \multicolumn{4}{|c|}{$\mathrm{T}=20^{\circ} \mathrm{C}$} & \multicolumn{4}{|c|}{$\mathrm{T}=40^{\circ} \mathrm{C}$} & \multicolumn{4}{|c|}{$\mathrm{T}=60^{\circ} \mathrm{C}$} \\
\hline & $\begin{array}{c}R= \\
0.05\end{array}$ & $\begin{array}{l}\mathrm{R}= \\
0.50\end{array}$ & $\begin{array}{l}\mathrm{R}= \\
1.00\end{array}$ & $\begin{array}{l}\mathrm{R}= \\
2.00\end{array}$ & $\begin{array}{l}\mathrm{R}= \\
0.05\end{array}$ & $\begin{array}{l}\mathrm{R}= \\
0.50\end{array}$ & $\begin{array}{l}\mathrm{R}= \\
1.00\end{array}$ & $\begin{array}{l}\mathrm{R}= \\
2.00\end{array}$ & $\begin{array}{l}\mathrm{R}= \\
0.05\end{array}$ & $\begin{array}{l}R= \\
0.50\end{array}$ & $\begin{array}{l}R= \\
1.00\end{array}$ & $\begin{array}{l}R= \\
2.00\end{array}$ \\
\hline 1 & 150 & 236 & 270 & 309 & 26.8 & 42.1 & 48.1 & 55.1 & 9.0 & 14.1 & 16.2 & $\overline{18.5}$ \\
\hline 2 & 121 & 186 & 219 & 249 & 20.6 & 33.0 & 38.1 & 43.5 & $6 . \overline{6}$ & $11 . \overline{7}$ & 13.3 & 15.4 \\
\hline 3 & 80 & 125 & 143 & 164 & 14.2 & 22.3 & 25.5 & 29.2 & 4.9 & 7.5 & 8.6 & 9.8 \\
\hline 4 & 201 & 319 & 355 & 417 & 35.3 & 52.0 & 60.3 & 70.1 & 12.4 & 19.5 & 22.1 & 25.3 \\
\hline 5 & 156 & 244 & 280 & 314 & 27.8 & 43.6 & 49.9 & 52.9 & 9.2 & 14.7 & 17.0 & 19.5 \\
\hline 6 & 106 & 167 & 192 & 219 & 17.2 & 29.1 & 33.6 & 39.0 & 6.1 & 10.4 & 11.6 & $13 . \overline{3}$ \\
\hline 7 & 118 & 185 & 211 & 237 & 21.0 & 33.0 & 37.7 & 38.9 & 6.5 & 11.1 & 2.7 & 14.5 \\
\hline 8 & 90 & 141 & 166 & 184 & 15.4 & 24.0 & 27.9 & 32.2 & 5.5 & 8.8 & 10.4 & 11.4 \\
\hline 9 & 72 & 113 & 128 & 149 & 12.8 & 20.0 & 22.9 & 26.2 & 4.1 & 6.7 & 7.7 & 8.8 \\
\hline 10 & 136 & 214 & 242 & 280 & 23.6 & 37.3 & 42.8 & 44.1 & 8.2 & $13 \overline{6}$ & 15.1 & 16.9 \\
\hline 11 & 175 & 274 & 311 & 363 & 30.5 & 48.9 & 56.0 & 59.9 & 10.2 & 16.4 & 18.8 & 21.6 \\
\hline 12 & 127 & 198 & 227 & 261 & 19.7 & 34.2 & 39.7 & 46.4 & 7.3 & 11.9 & 14.0 & 15.9 \\
\hline 13 & 157 & 250 & 280 & 317 & 28.1 & 44.0 & 50.4 & 55.3 & 9.8 & 14.8 & $17 . \overline{2}$ & 19.4 \\
\hline 14 & 87 & 137 & 156 & 171 & 15.0 & 23.4 & 26.7 & 31.9 & 5.2 & 8.8 & 9.4 & 10.7 \\
\hline 15 & 103 & 165 & 189 & 207 & 18.3 & 28.7 & 32.9 & 33.6 & 6.5 & 9.9 & 11.5 & 13.0 \\
\hline 16 & 87 & 137 & 160 & 179 & 15.0 & 23.6 & 27.1 & 31.2 & 5.2 & 8.2 & 9.4 & 11.2 \\
\hline 17 & 130 & 208 & 233 & 263 & 23.2 & 35.6 & 41.6 & 47.7 & 8.6 & 12.5 & 14.8 & 16.0 \\
\hline 18 & 106 & 167 & 194 & 219 & 18.2 & 29.8 & 33.3 & 38.1 & 6.5 & 10.0 & 11.7 & 13.0 \\
\hline 19 & 78 & 128 & 140 & 166 & 14.0 & 21.3 & 24.4 & 28.7 & $4 . \overline{7}$ & 7.7 & 8.4 & 9.8 \\
\hline 20 & 62 & 97 & 114 & 128 & 10.7 & 17.3 & 19.9 & 21.3 & 4.1 & 5.8 & 7.0 & 7.8 \\
\hline
\end{tabular}


C. 115 Mohamed Elsaid Abdel-Motaleb

Table 12: Predicted Values of $\mathrm{E}$ (psi) for the Investigated Mixes using the Developed Model (13)

\begin{tabular}{|c|c|c|c|c|c|c|c|c|c|c|c|c|}
\hline \multirow[b]{2}{*}{$\begin{array}{l}\text { Mix } \\
\text { No }\end{array}$} & \multicolumn{4}{|c|}{$\mathrm{T}=20^{\circ} \mathrm{C}$} & \multicolumn{4}{|c|}{$\mathrm{T}=40^{\circ} \mathrm{C}$} & \multicolumn{4}{|c|}{$\mathrm{T}=60^{\circ} \mathrm{C}$} \\
\hline & $\begin{array}{l}\mathrm{R}= \\
0.05\end{array}$ & $\begin{array}{l}R= \\
0.50\end{array}$ & $\begin{array}{l}R= \\
1.00\end{array}$ & $\begin{array}{l}\mathrm{R}= \\
2.00\end{array}$ & $\begin{array}{l}\mathrm{R}= \\
0.05\end{array}$ & $\begin{array}{l}R= \\
0.50\end{array}$ & $\begin{array}{l}R= \\
1.00\end{array}$ & $\begin{array}{l}\mathrm{R}= \\
2.00\end{array}$ & $\begin{array}{l}\mathbf{R}= \\
0.05\end{array}$ & $\begin{array}{l}R= \\
0.50\end{array}$ & $\begin{array}{l}R= \\
1.00\end{array}$ & $\begin{array}{l}R= \\
2.00\end{array}$ \\
\hline 1 & 28460 & 44692 & 51195 & 58645 & 6547 & 10281 & 11777 & 13491 & 2772 & 4352 & 4986 & 5711 \\
\hline 2 & 22843 & 35872 & 41092 & 47072 & 5255 & 8252 & 9453 & 10829 & 2225 & 3493 & 4002 & 4584 \\
\hline 3 & 14661 & 23023 & 26373 & 30210 & 3373 & 5296 & 6067 & 6950 & 1428 & 2242 & 2568 & 2942 \\
\hline 4 & 37247 & 58491 & 67002 & 76752 & 8568 & 13456 & 15414 & 17657 & 3627 & 5696 & 6525 & 7475 \\
\hline 5 & 29873 & 46911 & 53738 & 61558 & 6872 & 10792 & 12362 & 14161 & 2909 & 4569 & 5233 & 5995 \\
\hline 6 & 20001 & 31409 & 35979 & 41215 & 4601 & 7225 & 8277 & 9481 & 1948 & 3059 & 3504 & 4014 \\
\hline 7 & 22476 & 35295 & 40432 & 46315 & 5171 & 8120 & 9301 & 10655 & 2189 & 3437 & 3938 & 4511 \\
\hline 8 & 16848 & 26457 & 30307 & 34717 & 3876 & 6086 & 6972 & 7987 & 1641 & 2577 & 2952 & 3381 \\
\hline 9 & 260 & 20823 & 23853 & 27324 & 3050 & 4790 & 5487 & 6286 & 1291 & 2028 & 2323 & 2661 \\
\hline 10 & 25331 & 39778 & 45567 & 52197 & 5827 & 9151 & 10482 & 12008 & 2467 & 3874 & 4438 & 5083 \\
\hline 11 & 32726 & 51392 & 58870 & 67437 & 7529 & 11823 & 13543 & 15514 & 3187 & 5005 & 5733 & 6567 \\
\hline 12 & 23610 & 37075 & 42471 & 48651 & 5431 & 8529 & 9770 & 11192 & 2299 & 3611 & 4136 & 4738 \\
\hline 13 & 29358 & 46103 & 52811 & 60496 & 6754 & 10606 & 12149 & 13917 & 2859 & 4490 & 5143 & 5892 \\
\hline 14 & 16864 & 26483 & 30337 & 34752 & 3880 & 6092 & 6979 & 7994 & 1642 & 2579 & 2954 & 3384 \\
\hline 15 & 19211 & 30168 & 34558 & 39587 & 4419 & 6940 & 7950 & 9107 & 1871 & 2938 & 3366 & 3855 \\
\hline 16 & 16057 & 25216 & 28885 & 33089 & 3694 & 5801 & 6645 & 7612 & 1564 & 2456 & 2813 & 3222 \\
\hline 17 & 24864 & 39045 & 44727 & 51235 & 5720 & 8982 & 10289 & 11787 & $242 I$ & 3803 & 4356 & 4990 \\
\hline 18 & 20256 & 31808 & 36437 & 41739 & 4660 & 7317 & 8382 & 9602 & 1973 & 3098 & 3549 & 4065 \\
\hline 19 & 14740 & 23148 & 26516 & 30375 & 3391 & 5325 & 6100 & 6988 & 1436 & 2254 & 2582 & 2958 \\
\hline 20 & 11557 & 18149 & 20790 & 23816 & 2659 & 4175 & 4783 & 5479 & 1126 & 1768 & 2025 & 2319 \\
\hline
\end{tabular}

Table 13: Predicted Values of $\sigma$ (psi) for the Investigated Mixes using the Developed Model (14)

\begin{tabular}{|c|c|c|c|c|c|c|c|c|c|c|c|c|}
\hline \multirow{2}{*}{$\begin{array}{c}\text { Mix } \\
\text { No }\end{array}$} & \multicolumn{3}{|c|}{$\mathrm{T}=20^{\circ} \mathrm{C}$} & $\mathrm{R}=$ & $\mathrm{R}=$ & $\mathrm{R}=$ & $\mathrm{R}=$ & $\mathrm{R}=$ & $\mathrm{R}=$ & $\mathrm{R}=$ & $\mathrm{R}=$ & $\mathrm{R}=60^{\circ} \mathrm{C}$ \\
& 0.05 & 0.50 & 1.00 & 2.00 & 0.05 & 0.50 & 1.00 & 2.00 & 0.05 & 0.50 & $\begin{array}{c}\mathrm{R}= \\
1.00\end{array}$ & $\begin{array}{c}\mathrm{R}= \\
2.00\end{array}$ \\
\hline $\mathrm{I}$ & 151 & 236 & 269 & 307 & 25.7 & 39.9 & 45.6 & 52.1 & 9.1 & 14.1 & 16.2 & 18.5 \\
\hline 2 & 121 & 189 & 216 & 247 & 20.6 & 32.0 & 36.6 & 41.8 & 7.3 & 11.3 & 13.0 & 14.8 \\
\hline 3 & 78 & 121 & 138 & 158 & 13.2 & 20.5 & 23.5 & 26.8 & 4.7 & 7.3 & 8.3 & 9.5 \\
\hline 4 & 198 & 308 & 352 & 402 & 33.6 & 52.2 & 59.7 & 68.2 & 11.9 & 18.5 & 21.1 & 24.1 \\
\hline 5 & 159 & 247 & 282 & 322 & 26.9 & 41.9 & 47.8 & 54.6 & 9.5 & 14.8 & 16.9 & 19.3 \\
\hline 6 & 106 & 165 & 189 & 215 & 18.0 & 28.0 & 32.0 & 36.5 & 6.4 & 9.9 & 11.3 & 12.9 \\
\hline 7 & 120 & 186 & 213 & 243 & 20.3 & 31.6 & 36.1 & 41.2 & 7.2 & 11.2 & 12.8 & 14.6 \\
\hline 8 & 90 & 139 & 159 & 182 & 15.2 & 23.6 & 27.0 & 30.9 & 5.4 & 8.4 & 9.6 & 10.9 \\
\hline 9 & 71 & 110 & 125 & 143 & 12.0 & 18.6 & 21.3 & 24.3 & 4.2 & 6.6 & 7.5 & 8.6 \\
\hline 10 & 135 & 209 & 239 & 273 & 22.8 & 35.5 & 40.6 & 46.4 & 8.1 & 12.6 & 14.4 & 16.4 \\
\hline 11 & 174 & 271 & 309 & 353 & 29.5 & 45.9 & 52.4 & 59.9 & 10.4 & 16.2 & 18.6 & 21.2 \\
\hline 12 & 126 & 195 & 223 & 255 & 21.3 & 33.1 & 37.9 & 43.3 & 7.5 & 11.7 & 13.4 & 15.3 \\
\hline 13 & 156 & 243 & 277 & 317 & 26.4 & 41.2 & 47.0 & 53.7 & 9.4 & 14.6 & 16.7 & 19.0 \\
\hline 14 & 90 & 140 & 159 & 182 & 15.2 & 23.7 & 27.0 & 30.9 & 5.4 & 8.4 & 9.6 & 10.9 \\
\hline 15 & 102 & 159 & 181 & 207 & 17.3 & 26.9 & 30.7 & 35.1 & 6.1 & 9.5 & 10.9 & 12.4 \\
\hline 16 & 85 & 132 & 151 & 173 & 14.4 & 22.4 & 25.6 & 29.3 & 5.1 & 7.9 & 9.1 & 10.4 \\
\hline 17 & 132 & 205 & 234 & 268 & 22.4 & 34.8 & 39.7 & 45.4 & 7.9 & 12.3 & 14.1 & 16.1 \\
\hline 18 & 107 & 167 & 191 & 218 & 18.2 & 28.3 & 32.3 & 36.9 & 6.4 & 10.0 & 11.4 & 13.1 \\
\hline 19 & 78 & 122 & 139 & 159 & 13.3 & 20.6 & 23.6 & 26.9 & 4.7 & 7.3 & 8.3 & 9.5 \\
\hline 20 & 61 & 95 & 109 & 124 & 10.4 & 16.1 & 18.4 & 21.1 & 3.7 & 5.7 & 6.5 & 7.5 \\
\hline
\end{tabular}


Mansoura Enginecring Journal, (MEJ), Vol. 31, No. 1, March 2006.

C. 116

Table 14: Predicted Values of $\varepsilon$ (\%) for the Investigated Mixes using the Developed Model (15)

\begin{tabular}{|c|c|c|c|c|c|c|c|c|c|c|c|c|}
\hline \multirow{2}{*}{$\begin{array}{l}\text { Mix } \\
\text { No }\end{array}$} & \multicolumn{4}{|c|}{$\mathrm{T}=20^{\circ} \mathrm{C}$} & \multicolumn{4}{|c|}{$\mathrm{T}=40^{\circ} \mathrm{C}$} & \multicolumn{4}{|c|}{$\mathrm{T}=60^{\circ} \mathrm{C}$} \\
\hline & $\begin{array}{l}R= \\
0.05\end{array}$ & $\begin{array}{l}\mathrm{R}= \\
0.50\end{array}$ & $\begin{array}{l}R= \\
1.00\end{array}$ & $\begin{array}{l}R= \\
2.00\end{array}$ & $\begin{array}{l}\mathrm{R}= \\
0.05\end{array}$ & $\begin{array}{l}\mathrm{R}= \\
0.50\end{array}$ & $\begin{array}{l}\mathrm{R}= \\
1.00\end{array}$ & $\begin{array}{l}\mathrm{R}= \\
2.00\end{array}$ & $\begin{array}{l}\mathrm{R}= \\
0.05\end{array}$ & $\begin{array}{l}\mathrm{R}= \\
0.50\end{array}$ & $\begin{array}{l}R= \\
1.00\end{array}$ & $\begin{array}{l}R= \\
2.00\end{array}$ \\
\hline 1 & 8.6 & 7.9 & 7.7 & 7.5 & 9.6 & 8.9 & 8.6 & 8.4 & $10 . \overline{3}$ & 9.5 & 9.2 & 9.0 \\
\hline 2 & 8.8 & 8.1 & 7.9 & 7.7 & 9.9 & 9.1 & 8.9 & 8.6 & 10.5 & 9.7 & 9.4 & $9 . \overline{2}$ \\
\hline 3 & 9.2 & 8.5 & 8.3 & 8.1 & 10.3 & 9.5 & 9.3 & 9.0 & 11.0 & 10.1 & 9.9 & 9.6 \\
\hline 4 & 8.3 & $7 . \overline{6}$ & 7.4 & 7.3 & 9.3 & 8.5 & $8 . \overline{3}$ & 8.1 & 9.9 & 9.1 & 8.9 & $\overline{8.6}$ \\
\hline 5 & 8.6 & 7,9 & $7 . \overline{7}$ & 7.5 & 9.6 & 8.8 & 8.6 & 8.4 & 10.2 & 9.4 & $9 . \overline{2}$ & 9.0 \\
\hline 6 & 9.1 & 8.3 & 8.1 & 7.9 & 10.1 & 9.3 & 9. [ & 8.9 & 10.8 & 10.0 & 9.7 & 9.5 \\
\hline 7 & 8.9 & 8.2 & 8.0 & 7.8 & 9.9 & 9.1 & 8.9 & $8 . \overline{7}$ & 10.6 & 9.8 & 9.5 & 9.3 \\
\hline 8 & 9.1 & 8.4 & 8.2 & $8 . \overline{0}$ & 10.2 & 9.4 & 9.1 & $8 . \overline{9}$ & 10.9 & 10.0 & 9.7 & 9.5 \\
\hline 9 & 9.2 & 8.5 & 8.3 & 8.1 & 10.3 & 9.5 & 9.3 & $9 . \overline{0}$ & 11.0 & 10.1 & $9 . \overline{9}$ & 9.7 \\
\hline 10 & 8.7 & 8.0 & 7.8 & 7.6 & 9.7 & 8.9 & 8.7 & 8.5 & 10.3 & 9.5 & 9.3 & 9.1 \\
\hline 11 & 8.4 & 7.8 & 7.6 & 7.4 & 9.4 & 8.7 & $8 . \overline{5}$ & 8.2 & 10.0 & $9 . \overline{2}$ & 9.0 & 8.8 \\
\hline 12 & 8.7 & 8.0 & 7.8 & 7.6 & 9.8 & 9.0 & 8.8 & 8.5 & 10.4 & 9.6 & 9.3 & 9.1 \\
\hline 13 & 8.2 & 7.5 & 7.4 & 7.2 & 9.2 & $8 . \overline{4}$ & 8.2 & 8.0 & 9.8 & $9 . \overline{0}$ & 8.8 & 8.6 \\
\hline 14 & 9.4 & 8.7 & 8.5 & 8.2 & 10.5 & 9.7 & 9.4 & 9.2 & 11.2 & 10.3 & 10.1 & 9.8 \\
\hline 15 & 9.1 & 8.4 & $8 . \overline{2}$ & 8,0 & 10.2 & 9.4 & 9.1 & $8 . \overline{9}$ & 10.8 & 10.0 & 9.7 & 9.5 \\
\hline 16 & $9 . \overline{3}$ & 8.6 & 8.4 & 8.2 & 10.4 & 9.6 & 9.4 & 9.1 & 11.1 & 10.2 & 10.0 & 9.7 \\
\hline 17 & 8.5 & 7.8 & 7.6 & 7.4 & 9.5 & 8.7 & 8.5 & 8.3 & 10.1 & 9.3 & 9.1 & 8.9 \\
\hline 18 & 8.8 & 8.1 & 7.9 & 7.7 & 9.8 & 9.1 & 8.8 & 8.6 & 10.5 & 9.7 & 9.4 & 9.2 \\
\hline 19 & 9.6 & 8.9 & 8.6 & 8.4 & 10.8 & $9 . \overline{9}$ & 9.7 & 9.4 & 11.5 & 10.6 & 10.3 & 10.0 \\
\hline 20 & 9.9 & 9.1 & 8.8 & 8.6 & 11.0 & 10.1 & 9.9 & 9.6 & $11 . \overline{7}$ & 10.8 & 10.5 & 10.3 \\
\hline
\end{tabular}

Table 15: Predicted Valucs of $\mu$ for the Investigated Mines using the Developed Model (16)

\begin{tabular}{|c|c|c|c|c|c|c|c|c|c|c|c|c|}
\hline \multirow[b]{2}{*}{$\begin{array}{l}\text { Mix } \\
\text { No }\end{array}$} & \multicolumn{4}{|c|}{$\mathrm{T}=20^{\circ} \mathrm{C}$} & \multicolumn{4}{|c|}{$\mathrm{T}=40^{\circ} \mathrm{C}$} & \multicolumn{4}{|c|}{$T=60^{\circ} \mathrm{C}$} \\
\hline & $\begin{array}{l}R= \\
0.05\end{array}$ & $\begin{array}{l}\mathrm{R}= \\
0.50\end{array}$ & $\begin{array}{l}\mathrm{R}= \\
1.00\end{array}$ & $\begin{array}{l}\mathrm{R}= \\
2.00\end{array}$ & $\begin{array}{l}R= \\
0.05\end{array}$ & $\begin{array}{l}R= \\
0.50\end{array}$ & $\begin{array}{l}\mathrm{R}= \\
1.00\end{array}$ & $\begin{array}{l}\mathrm{R}= \\
2.00\end{array}$ & $\begin{array}{l}\mathrm{R}= \\
0.05\end{array}$ & $\begin{array}{l}\mathrm{R}= \\
0.50\end{array}$ & $\begin{array}{l}R= \\
1.00\end{array}$ & $\begin{array}{l}R= \\
2.00\end{array}$ \\
\hline 1 & 0.20 & 0.17 & 0.16 & 0.15 & 0.43 & 0.39 & 0.36 & 0.34 & 0.70 & 0.61 & 0.59 & 0.56 \\
\hline 2 & 0.21 & 0.18 & 0.17 & 0.16 & 0.46 & $0 . \overline{42}$ & $0 . \overline{38}$ & 0.37 & 0.75 & 0.66 & $0.6 \overline{3}$ & 0.60 \\
\hline 3 & 0.23 & 0.20 & 0.19 & 0.18 & 0.52 & 0.47 & $\overline{0.43}$ & 0.42 & 0.85 & $0 . \overline{74}$ & $0 . \overline{71}$ & 0.68 \\
\hline 4 & $0 . \overline{8}$ & 0.15 & 0.14 & 0.13 & 0.38 & 0.35 & 0.32 & 0.31 & 0.63 & $0.5 \overline{5}$ & $0.5 \overline{2}$ & 0.50 \\
\hline 5 & $0 . \overline{19}$ & 0.17 & 0.15 & 0.15 & 0.43 & 0.39 & 0.36 & 0.34 & 0.70 & 0.61 & $0 . \overline{58}$ & 0.56 \\
\hline 6 & 0.23 & 0.20 & 0.18 & 0.17 & 0.50 & $\widehat{0.45}$ & $0 . \overline{42}$ & 0.40 & 0.82 & 0.71 & 0.68 & 0.65 \\
\hline 7 & 0.21 & 0.18 & 0.17 & 0.16 & 0.47 & 0.43 & 0.39 & 0.37 & 0.76 & $0 . \overline{66}$ & 0.64 & 0.61 \\
\hline 8 & 0.23 & 0.20 & 0.18 & 0.17 & 0.50 & 0.45 & 0.42 & 0.40 & 0.81 & 0.71 & 0.68 & 0.65 \\
\hline 9 & 0.23 & 0.20 & 0.19 & 0.18 & 0.52 & 0.47 & 0.43 & 0.42 & 0.85 & $0 . \overline{74}$ & 0.71 & 0.68 \\
\hline 10 & 0.20 & 0.17 & 0.16 & 0.15 & $0 . \overline{44}$ & 0.40 & 0.37 & 0.35 & 0.72 & 0.63 & 0.60 & 0.58 \\
\hline 11 & 0.19 & 0.16 & 0.15 & 0.14 & 0.41 & 0.37 & 0.34 & 0.33 & 0.66 & 0.58 & 0.55 & 0.53 \\
\hline 12 & 0.20 & 0.18 & 0.16 & 0.15 & 0.45 & 0.41 & $0 . \overline{37}$ & 0.36 & 0.73 & 0.63 & 0.61 & 0.58 \\
\hline 13 & 0.17 & 0.15 & 0.14 & 0.13 & 0.38 & 0.35 & 0.32 & 0.30 & 0.62 & $0 . \overline{54}$ & $0 . \overline{51}$ & 0.49 \\
\hline 14 & 0.24 & 0.21 & 0.19 & 0.19 & 0.54 & 0.49 & 0.45 & 0.43 & 0.88 & 0.77 & 0.73 & 0.70 \\
\hline 15 & 0.23 & 0.20 & 0.18 & 0.17 & 0.50 & 0.46 & 0.42 & 0.40 & 0.82 & 0.71 & $0 . \overline{68}$ & 0.66 \\
\hline $1 \overline{6}$ & 0.24 & 0.21 & 0.19 & $0 . \overline{9}$ & 0.53 & $0 . \overline{49}$ & 0.45 & 0.43 & 0.87 & 0.76 & $0 . \overline{73}$ & 0.70 \\
\hline 17 & 0.19 & 0.17 & 0.15 & 0.15 & 0.42 & 0.39 & $0 . \overline{35}$ & 0.34 & 0.69 & 0.65 & 0.62 & 0.58 \\
\hline 18 & 0.21 & 0.18 & 0.17 & 0.16 & 0.47 & 0.43 & 0.39 & 0.37 & 0.76 & 0.67 & 0.64 & 0.61 \\
\hline 19 & 0.26 & 0.22 & 0.21 & 0.20 & 0.57 & 0.52 & 0.48 & 0.46 & 0.83 & 0.78 & 0.73 & 0.70 \\
\hline 20 & 0.27 & 0.24 & 0.22 & 0.21 & 0.60 & 0.54 & 0.50 & 0.48 & 0.89 & 0.86 & 0.77 & 0.75 \\
\hline
\end{tabular}

